\title{
Black urban consumers' status consumption of clothing brands in the emerging South African market
}

\author{
Adèle Cronje, Bertha Jacobs* and Arda Retief \\ Department of Consumer Science, University of Pretoria, Pretoria, SA, RSA
}

*Correspondence: Bertha Jacobs, Department of Consumer Science, Old-Agricultural Building, room 3-20, University of Pretoria, Pretoria 0002, RSA. E-mail: bertha.jacobs@up.ac.za

\begin{abstract}
Status concerns are noteworthy within a modern society as it is a key feature of individuals' social reputation. Engaging in this form of thinking results in particular patterns of consumption within consumer groups. In South Africa, Black urban consumers have newfound spending power and social mobility. This study investigated motivators of Black urban consumers' status consumption across different demographic variables (age, income and profession) in the South African (SA) emerging market. A survey research design was used to provide insights into the relationship of normative receptiveness (value expressive and utilitarian influences) and high self-monitoring as status consumption motivators of clothing brand consumption. The sample consisted of 246 Black urban consumers between the ages of 24 and 36, residing in Gauteng, South Africa and currently working in professional positions. The results of the study indicated that when purchasing clothing Black urban consumers are motivated by factors related to status consumption.
\end{abstract}

This study found no significant differences between age and gender variables in terms of status consumption. In terms of profession, all three motivational factors were significant. They proved to be very aware of the image that they communicate and how they are seen by others indicating that they are motivated especially by value expressiveness, utilitarian influences and high self-monitoring aspects across various professions.

\section{Introduction}

Consumers use status symbols to express and communicate particular meanings (i.e. social or economic standing) about themselves to the outside world (Belk, 1988). Similarly, individuals make assumptions about others' success based partly on the material things that they own (Richins, 2004). Research has pointed out that a lust for material goods is reflected in consumers' desire to climb the social status ladder (Alana, 2003) and is mirrored in their consumption patterns (O'Cass and McEwen, 2004; Clark et al., 2007). By purchasing products with inherited status symbolism consumers engage in status consumption (Goldsmith and Clark, 2012). Status consumption is the 'motivational process' (Eastman et al., 1999, p. 42) whereby individuals are driven to enhance their social position relative to others by purchasing products that have associated prominence or status to them and others in order to gain authority and power over others (O'Cass and McEwen, 2004). The value placed on perceived status and status enhancing goods may stem from 'economically deprived environments' or earlier periods where a person may have been denied certain things (Goldsmith et al., 2012). 
The Black consumer group, previously disadvantaged, is a vast growing and influential consumer group in the emerging South African market (White, 2011). These individuals and their parents come from suppressed and poverty-stricken pasts (Simpson and Dore, 2004) and underwent many social and political changes. Since the abolishment of Apartheid, they have been provided with newfound economic independence and have the opportunity to participate in the economy. The Black emerging middle class has grown from 1.7 million in 2004 to an estimated 4.2 million in 2014 with a collective spending power of $\$ 31$ billion (R400-billion) in 2012 (Steyn, 2013). Black economic empowerment, aimed at re-balancing economic inequalities after years of Apartheid, has played a key role in the transformational changes taking place in South Africa (Ponte et al., 2007; Tangri and Southall, 2008). Many Black South Africans were placed in higher ranking, higher paying positions as indicated by the increase in the number of Black workers used in skilled jobs coupled with an increase in income (Van der Berg and Louw, 2004). With their new accumulated wealth and higherpaying professional positions they were now able to spend money on luxury items and branded goods, especially clothing (Kaus, 2013; White, 2011). Fashion brands, particularly, hold prestige and status (Shermach, 1997) and are purchased primarily to satisfy this above mentioned status desire (Nia and Zaichkowsky, 2000). Black households in South Africa spend a higher proportion (6.8\%) of their disposable income on clothing and footwear relative to the proportions spent by Coloured (a mixed race population category, unique to South African, approximately $8.9 \%$ of total SA population) (5.1\%), Indian/Asian (3.3\%) and White (2.1\%) (Income and Expenditure Report, STATS SA, 2012). Moreover, Black South Africans spend roughly $50 \%$ more on visibly noticeable goods than Whites living in the same circumstances (Kaus, 2013) and were found to be far more fashion-conscious than their White counterparts (White, 2011).

Although the significant growth and the escalating spending power held by Black urban consumers is expected to increasingly influence clothing retail and purchasing patterns (PwC, 2012) limited information is available on their new needs and desires and what compel them to consume status products (e.g. clothing brands) with the intention of expressing personal status and success to others. To date many studies have focused on the differences in consumption of visible products between different race groups (Goyal, 2010; Kaus, 2013; Heffetz, 2011) or the factors affecting the status consumption of ethnic groups in countries such as Bolovia (Van Kempen, 2007) and Kuwait (Riquelme et al., 2011). Studies comparing status consumption between developed and developing countries (Üstüner and Holt, 2009; Shukla, 2010) also highlighted the differences between status consumption strategies of industrialized and less industrialized countries. There is also a great deal of 'guessing' around what drives the clear differences in status consumption between consumer groups within an emerging market context like South Africa (Heyik, 2011), Russia (Schimpfossl, 2014), and China (He et al., 2010). Lamont and Molnár (2001) found consumption to be an important mode for African-American consumers to 'signify and acquire equality, respect, acceptance and status' (p. 36) as well as vital in gaining a collective social identity that is without negative stereotypes. However, limited research exists related to other motivational factors compelling Black urban consumers to engage in status consumption of clothing brands. The purpose of this study was to empirically investigate whether normative receptiveness (value expressive and utilitarian influences) and selfmonitoring (high self-monitoring) are motivational factors for Black urban consumer to engage in status consumption of clothing brands in the South African emerging market. 
More specifically the study explored to what extent Black urban consumers' clothing brand consumption differs in terms of motivational factors related to status consumption (i.e. normative receptiveness: value expressive and utilitarian influences and high selfmonitoring) across various demographic variables (age, gender, disposable income and profession). It is important to note that this study does not claim that being black can account for or explain the status consumption of the sample. It merely aims to illustrate that within an emerging Black consumer group (a predominantly upcoming middle class in SA) a number of variables could explain their status consumption. The same might be true for any other emerging population group or homogenous sample. This study contributes to better insight regarding the driving forces behind the clothing brand purchasing decisions of emerging markets. Emerging markets are in transition and are often described in terms of their accelerated expansion with regard to social, economic and business activity (The CocaCola Retailing Research Council, 2010). Marketing professionals, specifically, are central in transforming previous marginalized consumers to 'valuable' (p. 42) consumers through promoting prestige branding strategies and positive imagery that enhances social standing and counter negative typecasting (Lamont and Molnár, 2001). Additionally, it can provide national and international brands with know-how related to building and positioning their clothing brands to a new evolving consumer base in addition to maintaining their existing customers. Building brand awareness and encourage consumers to develop a preference for a brand is imperative for any brand (Keller, 2003) keeping in mind that consumers in emerging markets come from vastly different backgrounds with diverse needs to be satisfied.

\section{Literature review}

\section{Status consumption}

Previously, the constructs of conspicuous and status consumption were used interchangeably. The act of status-seeking has been assumed to be materialistic due to its conspicuous nature as well as the signalling power of the particular products purchased (Kwon and Kwon, 2013). However, later research conducted by O'Cass and McEwen (2004) proved these constructs to be empirically different. Conspicuous consumption underlines the display of wealth through the consumption of luxurious products and services (Trigg, 2001). Whereas status consumption implies a social element to consumption, where consumers who aspire to enhance their social position and status by acquiring status symbols are very much attuned to the views of others (Dittmar, 1992). More clearly, status consumption refers to a form of power that consists of respect; consideration and envy from others that represent the soul of culture (Sundie et al., 2011). Individuals are influenced by their cultural norms and the expectations and rules of their reference groups. They therefore purchase products that have meaning not only to them but to their reference groups as well (Leigh and Gabel, 1992). Consumers do not only shop to satisfy their needs, but they also shop to satisfy an image that others might have of them. Thus their shopping is socially motivated. Status consumption can be seen as a construct that involves an internal need for status but also a desire to impress others as well as have authority over others (Eastman et al., 1999). O'Cass and McEwen (2004) proposed that status consumption is motivated by both interpersonal influences and self-monitoring aspects. 


\section{Interpersonal influences}

Interpersonal influences relate to the impact that others have on a consumer's behaviour (Ang et al., 2001). Additionally, it involves the need to conform to the expectations of others when making consumption decisions and to learn about services, products and brands through observing others and/or seeking information from others when making consumption decisions (Bearden et al., 1989). Interpersonal influences consist of normative receptiveness and informational receptiveness (Ang et al., 2001). For the purposes of this study the informational dimension will not be measured as this requires seeking information from personal and professional sources prior to buying products to reduce the risk of making the wrong decision (Goldsmith and Clark, 2012). Normative receptiveness affects purchase decisions that are based on consumers' expectation of what would impress others (Ang et al., 2001). Normative receptiveness consists of two dimensions namely, value expressiveness and utilitarian influence.

Value expressiveness refers to an individual's aspiration/need to enhance his/her self-image by association with a specific reference group (Bearden et al., 1989). This can be achieved through wearing similar clothing brands or dressing in similar styles to the reference group (Kaiser, 1997). Value expressiveness operates through the process of identification, which occurs when an individual assumes certain opinions or behaviours of others because it is associated with satisfying a self-defining relationship (Bearden et al., 1989). This is a way of matching one's self image with that of one's social world (Simpson et al., 2008).

Utilitarian influence, the other dimension of normative receptiveness is reflected in an individual's attempt to comply with the expectations of others to achieve rewards or avoid punishment and it operates through the process of compliance of what is appropriate (Bearden et al., 1989; Kaiser, 1997). An individual's self-concept is enhanced by positive responses from significant others which reinforce his or her behaviour as these responses function as positive rewards (Hogg et al., 2000). By purchasing acceptable or appropriate products consumers are able to avoid experiencing feelings of not belonging (Simpson and Dore, 2004) and are rewarded by being accepted by the group (Kaiser, 1997).

\section{Self-monitoring}

Self-monitoring is the tendency to be attuned to socially appropriate behaviour and to modify one's behaviour accordingly (Snyder and Gangestad, 1986; Auty and Elliott, 1998). Self-monitoring tendencies also refer to people's willingness and ability to regulate and control their own appearance and communicative behaviour (Kaiser, 1997). High selfmonitors are attuned to interpersonal cues (what others think) and will purposely manage their appearance and behaviour to have control over the social situation and their selfexpression (Kaiser, 1997). Individuals with high self-monitoring traits are highly aware of the messages that clothing sends and act and dress in a way that creates certain impressions in the minds of others (Browne and Kaldenberg, 1997). The clothes high self-monitors wear are consciously selected in order to skilfully manipulate their image and present themselves as others would like them to be seen (Riquelme et al., 2011). This affects consumption as individuals buy specific products such as branded clothing to maintain a 'front' that conveys a specific image to others (Snyder and Gangestad, 1986). This 'chameleon-like' quality is 
typical of high self-monitoring individuals who may seem to be different people in different situations (Browne and Kaldenberg, 1997, p. 32). High self-monitors consume high-status or status-laden products to project the desired message and illicit desired responses from their reference group thereby influencing status consumption (Auty and Elliott, 1998). They know that certain clothing brands provide them with control, authority and power over their social or reference group.

\section{Clothing brands as status symbols}

Individuals use clothing to convey or communicate their importance or social standing in society (Kaiser, 1997; O'Cass and Frost, 2002). Solomon (1999) held that status is achieved by consumers who acquire products (e.g. clothing brands) and experiences that they believe will validate their standing among others and make them appear more successful. Therefore, status entails consumption to communicate aspects of success to others (Soltani and Gharbi, 2013). One way of achieving recognition within a group is through purchasing brands that convey status and are deemed important by significant others or the peer group (O'Cass and Frost, 2002). Wearing clothing with a certain brand or image can benefit individuals through recognition by others and can create positive feelings of having personal 'good taste' in brand choice (Langer, 1997). Brands assist in creating a consumer's identity and give them something to relate to and also provide them with a sense of accomplishment (O'Cass and McEwen, 2004). Visible consumption such as clothing brand promotes a way for individuals to quantify their success and perhaps demonstrate their belonging to an 'elite' group in society (Lamont and Molnár, 2001; Fitzmaurice and Comegys, 2006). The more prominence, prestige or status a brand carries, the more likely it will be used in status consumption (O'Cass and McEwen, 2004).

\section{Methodology}

To investigate the factors that motivate Black urban consumers in the South African emerging market to engage in status consumption of clothing brands, a survey research design was followed. Data were collected through a pre-tested self-administered questionnaire developed from existing reliable scales. The first section included open-ended questions addressing general demographic information about the sample. These questions related to the respondents' age, gender, income, profession and geographic location. The second section included items that measured the motivational constructs related to status consumption namely, normative receptiveness (value expressiveness and utilitarian influences) and self-monitoring (high self-monitoring) using a 5-point Likert scale, ranging from 'never' $=1$, to 'always' $=5$.

Normative receptiveness (value expressiveness and utilitarian influences) was measured by items adapted from Bearden et al.'s (1989), reference group influence scale. Only the normative items were adapted and used in this study. The scale proved to be valid and reliable and links were found with other constructs that confirmed convergent and discriminant validity (Bearden et al., 1989). The self-monitoring tendencies scale, a revision of Lennox and Wolfe's (1984) revised self-monitoring scale (RSMS), was adapted and used to measure the self-monitoring construct. The RSMS consists of seven items that reveal an 
individual's ability to modify his/her self-presentation and six items reflect an individual's sensitivity to the expressive behaviour of others (O'Cass, 2000).

\section{Sample and sampling procedure}

Two hundred and forty six $(n=246)$ usable questionnaires were completed by young Black urban consumers, living in Gauteng, South Africa. The target population for this study consisted of Black urban consumers, a rapidly growing consumer segment in South Africa with growing disposable incomes and used at the centre of the corporate world (Simpson and Dore, 2004, p. 110). This consumer group was also found to be more likely to engage in consuming socially visible products such as clothing brands (Kaus, 2013) possibly due to their previous disadvantage backgrounds (Goldsmith et al., 2012) and the emphasis their culture places on social class and power (Marcoux et al., 1997; Simpson and Dore, 2004).

A non-probability, purposive sampling technique was used for this study. Purposive sampling is when the researcher selects a 'typical' sample of the population, depending on the willingness and availability of the respondents (Terreblanche et al., 2006, p. 139). Although this method is less representative of the population than other methods, it targets the specific demographic sample and the results are more accurate. Contacts and/or informants at large companies such as law firms (Webber \& Wentzel, Norton Rose, etc.), accounting firms (KPMG, Price Waterhouse Coopers etc.), mining headquarters (UMK, BHP Billiton), engineering firms (Bateman Engineering, DRA, GOBA, Hatch, Davis Langdon, BKS etc.), hospitals or other medical institutes as well as schools and universities were approached to gain access to possible respondents. These companies/institutions were selected because of the number of professional people that work for them which increased the probability of reaching the appropriate demographic group. The informants at these companies were provided with the demographic criteria of the sample and were requested to distribute the questionnaires via email or paper-based (if requested) to willing young Black employees ranging between the ages of 24 and 36 .

\section{Data analysis}

SPSS version 22 was used to perform statistical analysis. Scale reliability of the motivational constructs was assessed using Cronbach's $\alpha$ which indicated a high reliability for value expressiveness $(\alpha=0.87)$ and utilitarian influences $(\alpha=0.76)$ and an allowable reliability for high self-monitoring ( $\alpha=0.60$ ) (Tovakol and Donnick, 2011). To determine motivational differences in status consumption related to value expressiveness, utilitarian influence and high self-monitoring across age, gender, disposable income and profession groups, MANOVAs were performed. Levene's test for equality of variance was used to determine the homogeneity of variance, requiring that the variability of the respective groups must be the same and significant at $P \leq 0.05$ (Field and Miles, 2010). MANOVAs permitted the comparison of the means of the dependent variables (value expressiveness, utilitarian influence and high self-monitoring) across the independent variables (age, gender, disposable income and profession) significant at $P<0.0001$ (Cooper and Schindler, 2008). Fstatistics were calculated to test the null hypothesis, that there was no difference in the means of the dependent variables across the various groups formed by the categories of independent variables. The Wilk's Lambda test tested for multiple dependents to determine 
whether there was a significant difference in the means of the groups created by the independent variables. A smaller Wilk's Lambda value indicates a greater significance of the differences (Tustin et al., 2005). Post hoc Bonferroni tests $(\alpha=0.05)$ were calculated to ascertain exactly where the differences in the means across income groups and various professions occur regarding the dependent variables.

\section{Results}

\section{Sample characteristics}

All the participants were Black consumers, with an average age of 25 years, living and working in Gauteng, South Africa. Almost two thirds of the respondents were female $(63.8 \%)$ and more than a third $(36.2 \%)$ were male. The age ranges were $24-29(63.5 \%)$ and 30-36 (36.5\%). More than half of the respondents (55.7\%) indicated that their disposable income is between R10 000 and R19 999 per month, with 19.2\% earning less than R10 000 and 25\% earning $\geq$ R20 000 per month. An individual with a monthly earning of R24 390 (\$1548) per month in 2015 qualify as being in the top one percent of all South Africans in terms of monthly income (STATS SA, 2015).

Respondents indicated belonging to various and diverse professions. To compare status consumption and profession, professions were grouped into groups consisting of related professions (see next discussion for the professions and groups formed). More than a quarter $(27.0 \%)$ of the respondents were grouped into the Education, Research and Health Care group consisting of professions such as academic, research, education, science, technology and health care. Legal professions (lawyers/attorneys) comprised $18.9 \%$ of the respondents. Respondents in professions such as finance, investors, banking, human resources, planning and logistics were grouped in the Financial, Banking and Corporate group (18.0\%). The remaining profession groups comprised of Administrative (14.8\%), Retail and Marketing Management comprising of fashion, retail, customer service and marketing professions (11.1\%) and Engineering, Mining and Construction (10.2\%). Most of the respondents (65.6\%) had a dress code at work. More than a third had a smart casual dress code $(36.5 \%)$ and the remaining respondents had a corporate: business suits (31.7\%); soft tailoring: tailored pants and button-up blouse/shirt (15.6\%), uniform (10.8\%) dress code. Only $5.4 \%$ had a casual or informal dress code where they were allowed to wear jeans, Tshirts and summer dresses (Table 1 ). 
Table 1. Cronbach's $\alpha$ for status consumption motivators

\section{Construct}

Items
Cronbach's a for

Construct

Normative receptiveness

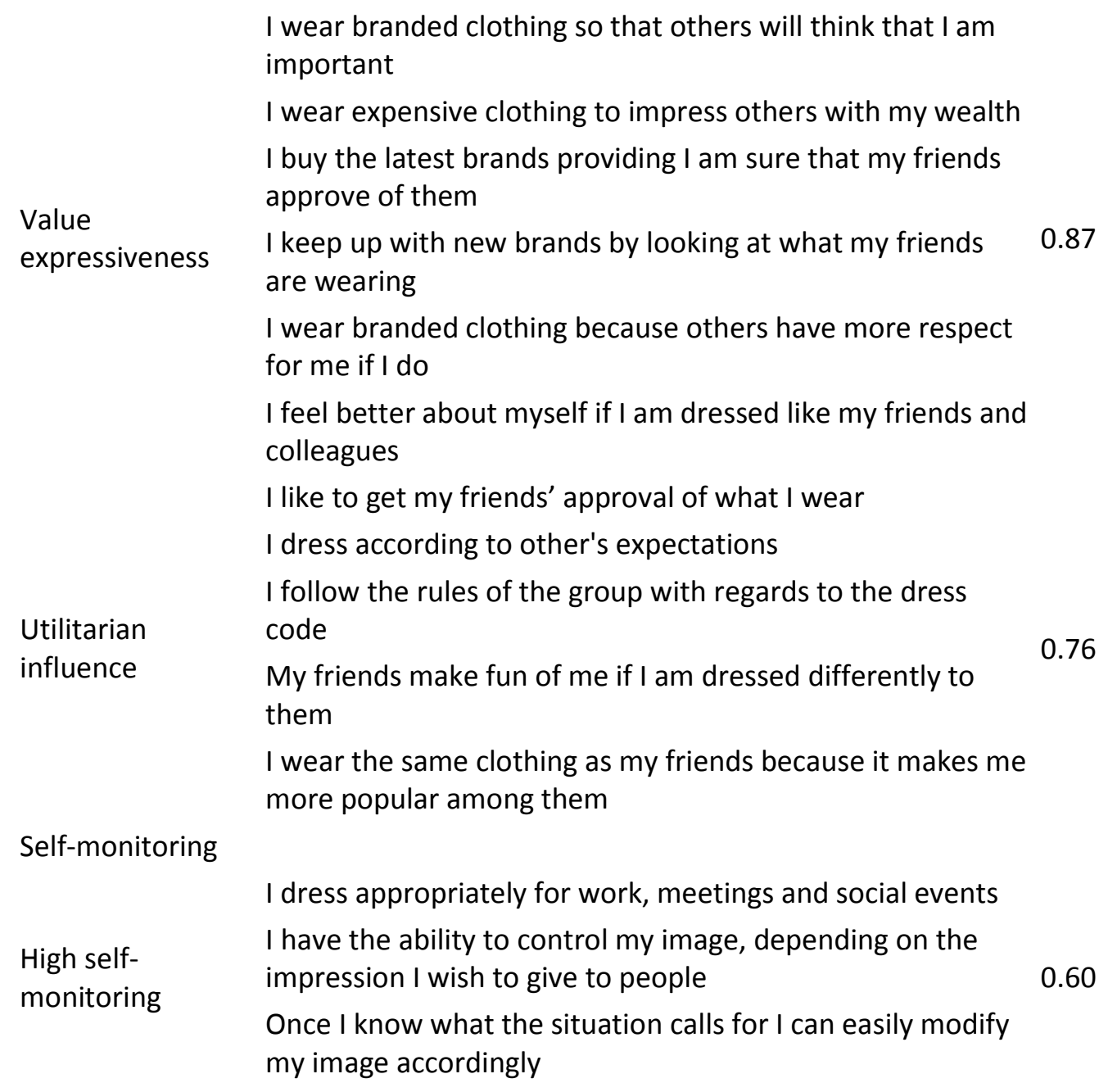

The recursive model was estimated using un-weighted least squares. The fit indices achieved from the confirmatory factor analysis indicated that the model had an acceptable fit on the key indices with $\chi^{2}=246.65 ; P=0.0001 ; \mathrm{AGFI}=0.959 ; \mathrm{RFI}=0.946 ; \mathrm{NFI}=0.955$ and an RMSEA of 0.083. A good model fit is indicated by an RMSEA value of 0.06 or less (Mazzocchi, 2008). The RMSEA value for the model was 0.083 which indicated a moderate model fit.

\section{Status consumption across age and gender}

After confirmatory factor analysis was done, MANOVAs were performed to test for motivational difference in terms of value expressiveness, utilitarian influences and highselfmonitoring across age and gender of Black urban consumers. The results of the MANOVA and Levene's tests for value expressiveness, utilitarian influences and high-self-monitoring are given in Table 2 . The results indicated no significance difference between the younger group (24-29 years) and the older group (30-36 years) in terms of value expressiveness, 
utilitarian influence and high self-monitoring. No significant difference was found between the means of value expressiveness, utilitarian influence and high self-monitoring across gender as the $p$-value for Wilk's Lambda was 0.204. The results showed that age and gender are not predictive of Black urban consumers' status consumption regarding clothing brands.

Table 2. MANOVA results for status consumption across age

\begin{tabular}{|c|c|c|c|c|c|}
\hline \multirow[b]{2}{*}{ Construct } & \multirow{2}{*}{$\begin{array}{c}24-29 \text { years } \\
n=155 \\
\text { Mean (SD) }\end{array}$} & \multirow{2}{*}{$\begin{array}{c}\text { 30-36 years } \\
(n=88) \\
\text { Mean (SD) }\end{array}$} & \multirow[t]{2}{*}{$\begin{array}{c}P \text { - } \\
\text { value }\end{array}$} & \multicolumn{2}{|c|}{$\begin{array}{l}\text { Levene's test for equality of } \\
\text { variance }\end{array}$} \\
\hline & & & & $F$ & Sig. \\
\hline $\begin{array}{l}\text { Value } \\
\text { expressiveness }\end{array}$ & $1.67(0.788)$ & $1.88(0.943)$ & 0.075 & 5.359 & 0.021 \\
\hline $\begin{array}{l}\text { Utilitarian } \\
\text { influences }\end{array}$ & $1.86(0.754)$ & $1.96(0.877)$ & 0.362 & 1.75 & 0.187 \\
\hline $\begin{array}{l}\text { High self- } \\
\text { monitoring }\end{array}$ & $4.03(0.802)$ & $3.97(0.760)$ & 0.374 & 0.003 & 0.94 \\
\hline
\end{tabular}

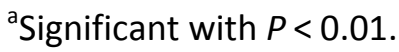

\section{Status consumption across disposable income}

The results obtained for the multivariate test indicated that the means for value expressiveness, utilitarian influence and high self-monitoring were all equal as indicated by Wilks' Lambda with a $F=1.611$ and $P=0.109$. F-statistics showed significant differences across the four income groups for the dependent constructs value expressiveness $(P=0.037)$ utilitarian influence $(P=0.017)$ but not for high self-monitoring $(P=0.570)$. The grand means were $M_{\text {Value expressiveness }}=1.751$ and $M_{\text {Utilitarian influence }}=1.895$ and $M_{\text {High self- }}$ monitoring $=4.019$. The means for value expressiveness across the four income groups differed significantly and ranged between 1.56 (income $\geq R 20000$ ) and 1.98 (R10 000-R14, 999). The means for utilitarian influence across the various income groups also differed significantly from 1.77 (income $\geq$ R20 000) to 2.15 (R10 000-R14 999). However, no significant difference across the various income groups for high self-monitoring occurred.

The income groups that showed the greatest difference when related to value expressiveness and utilitarian influence were between the income groups R10 000-R14 999 and $\geq R 20$ 000. The post hoc Bonferroni test indicated that there was a significant difference between individuals earning R10 000-R14 999 and individuals earning a disposable income $\geq \mathrm{R} 20000(P=0.028)$ in terms of value expressiveness. This indicates that individuals earning $\geq$ R20 000 per month are less motivated by value expressiveness compared with individuals earning between R10 000 and R14 999 per month. Similar results were found for utilitarian influence. Individuals earning R10 000-R14 999 per month differed significantly $(P=0.034)$ from individuals earning $\geq \mathrm{R} 20000$, indicating that Black urban consumers earning R10 000-R14 999 are more motivated by utilitarian influence than those earning $\geq$ R20 000 per month. These differences are presented in Table 3. 
Table 3. Post hoc Bonferroni: status consumption and disposable income

\begin{tabular}{|c|c|c|c|c|c|}
\hline \multirow[t]{6}{*}{$\begin{array}{l}\text { Dependent } \\
\text { variable }\end{array}$} & $\begin{array}{c}\text { Disposable income } \\
\text { groups (I) }\end{array}$ & $\begin{array}{c}\text { Disposable income } \\
\text { groups }(J)\end{array}$ & $\begin{array}{c}\text { Mean } \\
\text { diff.(I-J) }\end{array}$ & $\begin{array}{l}\text { Std. } \\
\text { Error }\end{array}$ & Sig. \\
\hline & & 10 000-14999 & -0.258 & 0.160 & 0.645 \\
\hline & 5000-9 999 & 15 000-19999 & 0.009 & 0.168 & 1.00 \\
\hline & & $\geq 20000$ & 0.166 & 0.168 & 1.00 \\
\hline & & 5000-9 999 & 0.258 & 0.160 & 0.645 \\
\hline & $10000-14999$ & 15 000-19999 & 0.268 & 0.148 & 0.439 \\
\hline \multirow{12}{*}{$\begin{array}{l}\text { Value } \\
\text { expressiveness }\end{array}$} & & $\geq 20000$ & $0.425^{a}$ & 0.148 & 0.028 \\
\hline & & 5 000-9 999 & -0.009 & 0.168 & 1.00 \\
\hline & 15 000-19999 & $10000-14999$ & -0.268 & 0.148 & 0.439 \\
\hline & & $\geq 20000$ & 0.157 & 0.157 & 1.00 \\
\hline & & 5000-9 999 & -0.166 & 0.168 & 1.00 \\
\hline & $\geq 20000$ & $10000-14999$ & $-0.425^{a}$ & 0.148 & 0.028 \\
\hline & & 15 000-19999 & -0.157 & 0.157 & 1.00 \\
\hline & & $10000-14999$ & -0.334 & 0.148 & 0.152 \\
\hline & 5000-9 999 & 15 000-19999 & 0.001 & 0.156 & 1.00 \\
\hline & & $\geq 20000$ & 0.051 & 0.156 & 1.00 \\
\hline & & 5 000-9 999 & 0.334 & 0.148 & 0.152 \\
\hline & $10000-14999$ & 15 000-19999 & 0.335 & 0.138 & 0.096 \\
\hline \multirow{7}{*}{$\begin{array}{l}\text { Utilitarian } \\
\text { influence }\end{array}$} & & $\geq 20000$ & $0.385^{\mathrm{a}}$ & 0.138 & 0.034 \\
\hline & & 5 000-9 999 & -0.001 & 0.156 & 1.00 \\
\hline & 15 000-19999 & 10 000-14999 & -0.335 & 0.138 & 0.096 \\
\hline & & $\geq 20000$ & 0.050 & 0.146 & 1.00 \\
\hline & & 5 000-9 999 & -0.051 & 0.156 & 1.00 \\
\hline & $\geq 20000$ & $10000-14999$ & $-0.3851^{a}$ & 0.138 & 0.034 \\
\hline & & $15000-19999$ & -0.050 & 0.146 & 1.00 \\
\hline
\end{tabular}

${ }^{a}$ The mean difference is significant at the 0.05 level.

\section{Status consumption across professions}

F-statistics $(F=4.247 ; P<0.0001)$ showed significant differences in all three of the motivational measures of status consumption when comparing profession, indicating that at least two of the means for value expressiveness, utilitarian influence and high selfmonitoring differed. The three dependent constructs had significant different means at $P<0.0001$ for value expressiveness and utilitarian influence and for high self-monitoring, $P<0.001$. The grand means were $M_{\text {Value expressiveness }}=1.695, M_{\text {Utilitarian influence }}=1.851$ and $M_{\text {High }}$ self-monitoring $=3.968$. The mean for value expressiveness across the six groups of professions differed significantly and ranged between 1.364 (Financial, Banking and Corporate) and 2.254 (Education, Research and Health Care). The means for utilitarian influence across the various income groups also differed significantly from 1.536 (Financial, Banking and Corporate) to 2.339 (Education, Research and Health Care). Finally the difference across the 
various professions for high self-monitoring was lowest for Retail and Marketing Management at 3.538 and highest for Financial, Banking and Corporate at 4.182.

The post hoc Bonferroni test indicated that there was a significant difference in value expressiveness when comparing the means of individuals working in Education, Research and Health Care professions to the means of those working in the Financial, Banking and Corporate professions at $P<0.0001$. There is also a significant difference between this group and individuals in the Legal profession at $P=0.001$. This indicates that there is noteworthy difference in the motivation of value expressiveness when comparing individuals in the Education, Research and Health Care professions to individuals in the Financial, Banking and Corporate and Legal professions. When measuring utilitarian influence it is noted that there is a significant difference between individuals working in the Education, Research and Health Care professions and the Financial, Banking and Corporate at $P<0.0001$. A significant difference, $P=0.004$, between this group (Education, Research and Health (are) and the Legal profession exist in terms of utilitarian influence.

Finally, a significant difference, $P=0.008$, is indicated in high self-monitoring between individuals in the Education, Research and Health Care professions and the Retail and Marketing Management. This indicates that high self-monitoring motivates Education, Research and Health Care as well as Legal professionals significantly more when comparing them to Retail and Marketing Management professionals. A $P$-value of 0.005 also indicates a significant difference between the Retail and Marketing Management professionals and the Legal profession indicating that individuals in the Legal professions are less motivated by high self-monitoring than those in Retail and Marketing Management professions. Table 4 depicts the post hoc Bonferroni test showing the significant difference in means between the various profession groups regarding status consumption.

Table 4. Post hoc Bonferroni: status consumption across professions

Dependent variable

\begin{tabular}{|c|c|c|}
\hline & & $\begin{array}{l}\text { Administrative } \\
\text { Engineering, Mining and } \\
\text { Construction }\end{array}$ \\
\hline \multirow[t]{5}{*}{$\begin{array}{l}\text { Value } \\
\text { expressiveness }\end{array}$} & $\begin{array}{l}\text { Education, Research and } \\
\text { Health Care }\end{array}$ & $\begin{array}{l}\text { Retail and Marketing } \\
\text { Management }\end{array}$ \\
\hline & & $\begin{array}{l}\text { Financial, Banking and } \\
\text { Corporate }\end{array}$ \\
\hline & & Legal \\
\hline & & Administrative \\
\hline & & $\begin{array}{l}\text { Engineering, Mining and } \\
\text { Construction }\end{array}$ \\
\hline \multirow{4}{*}{$\begin{array}{l}\text { Utilitarian } \\
\text { influence }\end{array}$} & Education, Research and & Retail and Marketing \\
\hline & Health Care & Management \\
\hline & & $\begin{array}{l}\text { Financial, Banking and } \\
\text { Corporate }\end{array}$ \\
\hline & & Legal \\
\hline
\end{tabular}

Mean diff. Std. (I-J) error Sig. $0.4114 \quad 0.16958 \quad 0.240$

$0.6074 \quad 0.192210 .027$

$0.8904^{\mathrm{a}} \quad 0.15929<0.0001$

$\begin{array}{lll}0.6490^{\mathrm{a}} & 0.15720 & 0.001\end{array}$

$\begin{array}{llll}0.4116 & 0.15815 & 0.147\end{array}$

$\begin{array}{lll}0.5794 & 0.17925 & 0.021\end{array}$

$\begin{array}{lll}0.5932 & 0.17673 & 0.014\end{array}$

$0.8030^{\mathrm{a}} \quad 0.14855<0.0001$

$\begin{array}{lll}0.5437^{\mathrm{a}} & 0.14660 & 0.004\end{array}$ 


\begin{tabular}{|c|c|c|c|c|c|}
\hline \multirow[t]{5}{*}{$\begin{array}{c}\text { Dependent } \\
\text { variable }\end{array}$} & Professional groups (I) & Professional groups (J) & $\begin{array}{l}\text { Mean diff. } \\
(I-J)\end{array}$ & $\begin{array}{l}\text { Std. } \\
\text { error }\end{array}$ & Sig. \\
\hline & & Administrative & 0.1469 & 0.15636 & 1.000 \\
\hline & & $\begin{array}{l}\text { Engineering, Mining and } \\
\text { Construction }\end{array}$ & 0.4315 & 0.17723 & 0.235 \\
\hline & $\begin{array}{l}\text { Education, Research and } \\
\text { Health Care }\end{array}$ & $\begin{array}{l}\text { Retail and Marketing, } \\
\text { Management }\end{array}$ & $0.6131^{a}$ & 0.17474 & 0.008 \\
\hline & & $\begin{array}{l}\text { Financial, Banking and } \\
\text { Corporate }\end{array}$ & -0.0303 & 0.14687 & 1.000 \\
\hline \multirow{6}{*}{$\begin{array}{l}\text { High self- } \\
\text { monitoring }\end{array}$} & & Legal & -0.0586 & 0.14495 & 1.000 \\
\hline & & $\begin{array}{l}\text { Education, Research and } \\
\text { Health Care }\end{array}$ & $-0.6131^{a}$ & 0.17474 & 0.008 \\
\hline & & Administrative & -0.4662 & 0.19423 & 0.257 \\
\hline & $\begin{array}{l}\text { Retail and Marketing, } \\
\text { Management }\end{array}$ & $\begin{array}{l}\text { Engineering, Mining and } \\
\text { Construction }\end{array}$ & -0.1815 & 0.21139 & 1.000 \\
\hline & & $\begin{array}{l}\text { Financial, Banking and } \\
\text { Corporate }\end{array}$ & $-0.6434^{a}$ & 0.18667 & 0.010 \\
\hline & & Legal & $-0.6717^{a}$ & 0.18516 & 0.005 \\
\hline
\end{tabular}

${ }^{\mathrm{a}}$ The mean difference is significant at the 0.05 level.

\section{Discussion and conclusions}

Attaching status to products can provide apparel brands with a way to initiate growth in emerging markets (He et al., 2010). With a better understanding of what motivates consumers to purchase clothing brands with associated status can assist retailers and marketers in terms of product assortment, positioning and marketing strategy.

Demographic variables such as age, gender, income and profession can provide them with ways to segment markets and position status products accordingly.

\section{Value expressiveness, utilitarian influence, high-self-monitoring and age and gender}

The results of sample means and MANOVAs given in Table 2, respectively, show no significant differences for motivational factors of status consumption between the younger age group (24-29 years) and older age group (30-36 years). This is similar to the findings of Eastman and Liu (2012) who found no significant differences between each individual generational cohort and only a significant difference between Generation $Y$ and Baby Boomers. In their study Generation Y (born between 1977 and 1987) on average had the highest level of status consumption which confirm that younger generations overall (as the case with this study) are more prone to status consumption and are the key market for clothing marketers to focus on. Although previous studies with a diverse racial sample, found that men were more prone to express their identity (Browne and Kaldenberg, 1997) and women their social status (Segal and Podoshen, 2013) through material possessions and that men have more self-monitoring characteristics than women (O'Cass, 2001) this study found no significant differences between gender variables in terms of status consumption. It might be that both genders (due to the homogenous sample) are equally motivated by 
value expressiveness, utilitarian influence and high-self-monitoring factors to engage in status consumption of clothing.

\section{Value expressiveness, utilitarian influence, high-self-monitoring and income}

However, the post hoc Bonferroni test showed mixed support in terms of motivational factors of status consumption in terms of income. The motivational factors, value expressiveness (mean difference of 0.425 ) and utilitarian influence (mean difference of 0.385), was significantly higher between those earning R10 $000-R 14999$ vis-á-vis those earning $\geq$ R20 000 per month. The higher income group was significantly less motivated by value expressiveness and utilitarian influences than the middle income group.

Value expressiveness is reflected in an individual's desire to enhance his or her self-image through the association with a specific reference group. The findings suggest that Black consumers earning a low-middle income per month are more inclined to purchase branded clothing to match the clothing of their reference group. Consumers seek out status by buying similar styles or brands to their reference group and the opinions and consumption behaviour of the reference group gain prominence in their own behaviour (Clark et al., 2007). Whereas the higher earning income group was less driven to conform to their reference group and rather had the desire to stand out or be more individualistic by purchasing clothing brands with unique attributes that would enhance their need for novelty and uniqueness. This is in agreement with the findings of Clark (2006) who established the construct of consumer independence, confirming the tendency of consumers to not conform to reference group influences but instead to be motivated by personal taste and preferences in terms of brand choices. Clark (2006) also confirmed that consumer independence is positively related to the need for uniqueness and negatively related to social motivation for consumption and susceptibility to normative social influences.

Conversely, Black urban consumers in the low-middle income group are also more motivated by utilitarian influence, purchasing branded clothing merely to reflect a desired social status (Nelissen and Meijers, 2011) as well as to improve/reinforce their self-concept through positive responses about their branded clothing purchases from significant others (Hogg et al., 2000). The findings of this study suggest that high earning individuals do not feel the need to enhance their self-image by choosing clothes that are similar to those of their reference groups and are also not influenced by approval from their friends as indicated in studies conducted by Hogg et al. (2000). In accordance with He et al. (2010), higher income consumers' status consumption is rather motivated by the perception that high quality and high priced products equate good taste, uniqueness and sophistication and could institute respect from others, but their identity is not built around the approval of others.

Special care should be taken by marketers and retailers to study the reference groups to whom the lower-middle income consumers are comparing themselves. According to Corneo and Jeanne (1997) the 'bandwagon effect' which means to purchase goods because others are purchasing them might be the motive behind lower-middle income consumers' clothing brand purchases. This may motivate lower income individuals (within a reference group) to 
consume similar status goods in order to align themselves with their reference group or to another reference group that they wish to be a part of (Truong et al., 2008). As the middle income consumers earn more the need for uniqueness might grow and by offering unique products backed by social approval market share and brand equity will grow as well.

As far as high self-monitoring was concerned, the results were insignificant indicating that there is no difference between the different income groups. Black urban consumers from different income groups are equally motivated by high self-monitoring to engage in status consumption. The findings suggest that Black urban consumers think of themselves as being able to control their image and the impression they want to communicate to others.

\section{Value expressiveness, utilitarian influence, high-self-monitoring and profession}

In terms of profession, all three motivational factors were significant. Interestingly, individuals in Education, Research and Health Care professions were significantly more motivated by value expressiveness to engage in status consumption than those in Retail and Marketing Management, Financial, Banking and Corporate and Legal professions. Individuals in the Retail and Marketing Management, Financial, Banking and Corporate and Legal industries might be less motivated by value expressiveness due to strict dress codes including more corporate 'uniforms' such as business suits, making them less inclined to enhance their image to associate with a specific group as they experience the association by default. As indicated by Bearden et al. (1989) value expressiveness relates to individuals' adopting specific behaviours in order to satisfy self-defining relationships. Black urban consumers used in Education, Research and Health Care positions may be more motivated by value expressiveness to satisfy the image that they have of themselves and perhaps feel the need to match their self-image to that of the social world (Bearden et al., 1989; Simpson et al., 2008).

A similar difference between Education, Research and Health Care professions and Financial, Banking and Corporate and Legal professions was found for utilitarian influence. Black urban consumers in Education, Research and Health Care professions may want to avoid punishment for not wearing suitable attire to work (Kaiser, 1997) and instead want to adhere to social influences (Goldsmith and Clark, 2012). Through purchasing appropriate clothing they are able to avoid feelings of not belonging in their professions or to their social reference groups (Simpson et al., 2008). Black urban consumers in Education, Research and Health Care professions perform functions with more personal contact with students, learners or patients and there might be more pressure on these individuals to dress in a specific way and to comply with expectations as they, in many instances, do not have a prescribed dress code which makes for a more complicated process. Black urban consumers used in Financial, Banking and Corporate as well as Legal professions are less motivated by utilitarian influences. Perhaps due to the strict dress codes they need to adhere to as well as contact with clients and rarely being in a situation where they will receive rewards or punishment for what they wear.

Self-monitoring influences the manner in which individuals dress and present themselves to others (Kaiser, 1997). High self-monitors seem to be sensitive to the expressions and behaviours of others (Baron et al., 2006) and use social cues such as clothing styles, colours 
and brands to modify their self-presentation (Browne and Kaldenberg, 1997). In terms of high self-monitoring, the findings showed the greatest differences were between the Education, Research, and Health Care and the Retail, and Marketing Management professions as well as between the Retail and Marketing Management and Education, Research, and Health Care and Legal professions. Even though the results indicated that most Black urban consumers are high self-monitors significant differences exist in different professions. Education, Research and Health Care professions are more motivated by high self-monitoring as they would be most likely to be perceived as having the ability and competencies to perform certain tasks and would want to dress appropriately for all situations to communicate their capabilities (Kaiser, 1997). Further, it is expected that Black urban consumers used in Retail and Marketing Management professions would be more motivated by high self-monitoring than those in Legal professions as they are in direct contact with customer/clients and might want to signal their knowledge about products, sales skills or be approachable to customers in client service roles. Those working in Retail and Marketing Management professions may also be opinion leaders and should be able to prescribe to others what to wear or even how to play a different role in a different situation (Browne and Kaldenberg, 1997). Although the findings found the contrary for those in Legal professions, Kaiser (1997) confirms that economical and legal organisation usually prescribe certain dress codes for employees working with clients to portray competence and authority e.g. a layer in a court. Overall Black urban consumers are skilful high self-monitors and are aware and motivated by this trait to engage in status consumption of clothing brands to modify their image according to the situation at hand. Retailers have to remain aware of how items are branded as high self-monitors may completely disregard certain items if seen as not appropriate or not meeting the requirements for certain occasions. Further, marketers and brand managers should remain cautious that products are the building blocks of consumers' life style (He et al., 2010) and the status attributes incorporated in their products will directly influence a high self-monitor's decision to purchase products to support their status position in society.

Findings of this study have created some scope for retailers and marketers by providing insight into the motivations behind the purchasing decisions of Black urban consumers in the emerging South African market. Belk et al. (1982) support the purchase of goods merely for their symbolic value, however this consumer group's motivation for status consumption of clothing brands can be more complex and dynamic than expected as demographic variables such as age, gender and income are not clear indicators for status consumption. However, the professions proved to be better indicators for their motivation to engage in status consumption. Individuals tend to build their identity around what they do for a living or their profession which refers to their achieved identity and dress practices can be linked to the position someone holds in a workplace (Kaiser, 1997). It can be concluded that Black urban consumers are very aware of the image they project and they are very aware of what certain situations call for in terms of their clothing decision-making. Nevertheless, they are not driven to show-off their status, wealth or prestige as they are not interested in brands merely because of their 'snob-appeal' and to impress others with their money. They might be more interested in the fashion-value of the items as they do enjoy to stand out and not to fit in with the mainstream and thus do like to be noticed by others; not necessarily for the reference group that they are in but more for their individuality or professionalism. This underscores Lamont and Molnár's (2001) opinion that black consumers use consumption of 
products with high visibility and status to express their collective cultural distinctiveness through their unique taste. This complex group still requires much more research in order to obtain more in-depth knowledge of what motivates them to purchase certain clothing items.

\section{Limitations and possibilities for future research}

Findings of this study were limited to Black urban consumers living and working in Gauteng, South Africa. The findings can therefore not be generalised to the larger South African population or other emerging markets. Future studies could focus on other geographic locations to determine whether or not the results of this study hold true in other emerging markets or smaller ethnic market segments in developed markets. Comparative studies focusing on younger age groups in the Black consumer market, e.g. students and older groups e.g. $\geq 40$ could be useful to discover whether there are differences and similarities across these age groups. Qualitative studies could contribute in uncovering the deeper established drivers for status consumption and focussing on other psychographic and psychological aspects such as consumer socialisation, consumer innovativeness and hedonic desires. Imagery, personal interviews and focus group discussions could be used to stimulate participants visually and perhaps obtain more in depth answers. Future studies could also be conducted to ascertain whether Black urban consumers are more interested in the fashion-value of clothing items rather than the brand or the symbolic message provided by certain clothing items. The current study only focused on certain motivators for status consumption with no linkage to purchasing clothing for specific occasions or ceremonies such as weddings, funerals, baptisms, debuts or graduations which may instigate higher motivation for status consumption in emerging markets.

With a better understanding of this group marketers and retailers should be able to capture the Black urban market's attention and create a more loyal customer base with products catering to their need for standing out and being able to modify their appearance according to the situation. It is however recommended that more attention should be given to research of this market segment/group.

\section{Acknowledgements}

The authors wish to acknowledge Dr Marien Graham and Joyce Jordaan from the Department of Statistics at the University of Pretoria for assisting with the data analysis.

\section{References}

Alana, O. (2003) A word with the rich (Ja5:1-6) - part 1. Verbum et Ecclesia, 24, 1-14A.

Ang, S.H., Cheng, P.S., Lim, E.A.C. \& Tambyah, S.K. (2001) Spot the difference: consumer responses towards counterfeits. Journal of Consumer Marketing, 18, 219-235.

Auty, S. \& Elliott, R. (1998) Fashion involvement, self-monitoring and the meaning of Brands. Journal of Product and Brand Management, 7, 109-123. 
Baron, R.A., Byrne, D. \& Branscombe, N.R. (2006). Social Psychology. 11th ed. Pearson, Cape Town.

Bearden, W., Netemeyer, R. \& Teel, J. (1989) Measurement of consumer susceptibility to interpersonal influence. Journal of Consumer Research 15, 473-481.

Belk, R. (1988) Possessions and the extended self. Journal of Consumer Research, 15, 139168.

Belk, R., Bahn, K. \& Mayer, R. (1982) Developmental recognition of consumption symbolism. Journal of Consumer Research, 9, 4-17.

Browne, B. \& Kaldenberg, O. (1997) Conceptualizing self-monitoring: links to materialism and product involvement. Journal of Consumer Marketing, 14, 31-44.

Clark R. A. (2006). Consumer independence: Conceptualization, measurement and validation of a previously unmeasured social response tendency. Unpublished Doctoral Dissertation, Florida State University, Tallahassee, ProQuest.

Clark, R., Zboja, J. \& Goldsmith, R. (2007) Status consumption and role-relaxed consumption: a tale of two retail consumers. Journal of Retailing and Consumer Services, 14, 45-59.

Cooper, D.R. \& Schindler, P.S. (2008) Business Research Methods, 10th edn. McGraw Hill, Boston.

Corneo, G. \& Jeanne, O. (1997) Snobs, bandwagons and the origin of social customs in consumer behaviour. Journal of Economic Behavior and Organization, 32, 333-347.

Dittmar, H. (1992) The Social Psychology of Material Possessions. St Martin's Press, New York.

Eastman, J., Goldsmith, R. \& Flynn, L. (1999) Status consumption in consumer behaviour: scale development and validation. Journal of Marketing Theory and Practice, 7, 41-52.

Eastman, J. \& Liu, J. (2012) The impact of generational cohorts on status consumption: an exploratory look at generational cohort and demographics on status consumption. Journal of Consumer Marketing, 29, 93-102.

Field, A. \& Miles, J. (2010) Discovering Statistics Using SAS. Sage, London.

Fitzmaurice, J. \& Comegys, C. (2006) Materialism and social consumption. Journal of Marketing Theory and Practice, 14, 287-299.

Goldsmith, R. \& Clark, R. (2012) Materialism, status consumption, and consumer independence. Journal of Social Psychology, 152, 43-60. 
Goldsmith, R., Flynn, L. \& Clark, R. (2012) Materialistic, brand engaged and status consuming consumers and clothing behaviours. Journal of Fashion Marketing Management, 16, 102119.

Goyal, M. (2010) Black Diamonds. Forbes India, 21 June. [WWW document]. URL http://www.forbes.com/2010/06/21/forbes-india-black-diamonds-middle-classspending.html (accessed on May 2015).

He, Y., Zou, D. \& Jin, L. (2010) Exploiting the goldmine: a lifestyle analysis of affluent Chinese consumers. Journal of Consumer Marketing, 27, 615-628. [DOI

10.1108/07363761011086362]

Heffetz, O. (2011) A test of conspicuous consumption: visibility and income elasticities. Review of Economics and Statistics, 93, 1101-1117.

Heyik, M. (2011) Conspicuous consumption in South Africa: race, assets \& reference groups. A working paper, 1 August.

Hogg, M., Cox, A. \& Keeling, K. (2000) The impact of self-monitoring on image congruence and product/brand evaluation. European Journal of Marketing, 34, 641-666.

Kaiser, S.B. (1997) The Social Psychology of Clothing: Symbolic Appearances in Context. Fairchild Publications, New York.

Kaus, W. (2013) Conspicuous consumption and race: evidence from South Africa. Economics and Evolution, 1003, 1-21.

Keller, K. (2003) The multidimensionality of brand knowledge. Journal of Consumer Research, 29, 595-600.

Kwon, Y. \& Kwon, K. (2013) Cultural omnivores' consumption: strategic and inclusively exclusive. International Journal of Marketing Studies, 5, 118-127.

Lamont, M. \& Molnár, V. (2001) How blacks use consumption to shape their collective identity. Evidence from marketing specialists. Journal of Consumer Culture, 1, 31-45. doi: $10.1177 / 146954050100100103$.

Langer, J. (1997) What consumers wish brand managers knew. Journal of Advertising Research, 37, 60-65

Leigh, J. \& Gabel, T. (1992) Symbolic interactionism: its effects on consumer behaviour on consumer behaviour and implications for marketing strategy. Journal of Consumer Marketing, 9, 27-38.

Lennox, R. \& Wolfe, R. (1984) Revision of the self-monitoring scale. Journal of Personality and Social Psychology, 46, 1349-1364. 
Marcoux, J., Filiatrault, P. \& Chéron, E. (1997) The attitudes of underlying preferences of young urban educated Polish consumers towards products made in Western countries. Journal of International Consumer Marketing, 9, 5-29.

Mazzocchi, M. (2008) Statistics for marketing and consumer research. SAGE Publications, London.

Nelissen, R.M.A. \& Meijers, R.M.A. (2011) Social benefits of luxury brands as costly signals of wealth and status. Evolution and Human Behaviour, 32, 343-355.

Nia, A. \& Zaichkowsky, J. (2000) Do counterfeit devalue the ownership of luxury brands? Journal of Product and Brand Management, 9, 485-497.

O'Cass, A. (2000) A psychometric evaluation of a revised version of the Lennox and Wolfe revised self-monitoring scale. Psychology and Marketing, 17, 397-419.

O'Cass, A. (2001) Consumer self-monitoring, materialism and involvement in fashion clothing. Australasian Marketing Journal, 9, 46-60.

O'Cass, A. \& Frost, H. (2002) Status brands: examining the effects of non-product-related brand associations on status and conspicuous consumption. Journal of Product and Brand Management, 11, 67-88.

O'Cass, A. \& McEwen, H. (2004) Exploring consumer status and conspicuous consumption. Journal of Consumer Behaviour, 4, 25-39.

Ponte, S., Roberts, S. \& Van Sittert, L. (2007) "Black Economic Empowerment", business and the state in South Africa. Development and Change, 38, 933-955.

Price Waterhouse Coopers (2012) South African Retail and Consumer Products Outlook 2012-2016. PWC, South Africa.

Richins, M. (2004) The material values scale: measurement properties and development of a short form. Journal of Consumer Research, 31, 209-219.

Riquelme, H., Rios, R. \& Al-Sharhan, N. (2011) Antecedents of ostentatious consumption in Kuwait. Journal of Islamic Marketing, 2, 295-308.

Schimpfossl, E. (2014) Russia's social upper class: from ostentation to culturedness. British Journal of Sociology, 64, 63-81.

Segal, B. \& Podoshen, J. (2013) An examination of materialism, conspicuous consumption and gender differences. International Journal of Consumer Studies, 37, 189-198.

Shermach, K. (1997) What consumers wish brand managers knew. Marketing News, 31, 9.

Shukla, P. (2010) Status consumption in cross-national context. Socio-psychological, brand and situational antecedents. International Marketing Review, 27, 108-29. 
Simpson, J. \& Dore, B. (2004) Marketing in South Africa: Cases and Concepts, 3rd edn. Cape Town, Van Schaik Publishers.

Simpson, P., Siguaw, J. \& Cadogan, J. (2008) Understanding the consumer propensity to observe. European Journal of Marketing, 42, 196-222.

Snyder, M. \& Gangestad, S. (1986) On the nature of self-monitoring: matters of assessment, matters of validity. Journal of Personality and Social Psychology, 51, 125-139.

Statistics South Africa (2012) Income and expenditure of households 2010/2011: Statistical release P0100.6 November. Statistics South Africa, Pretoria. [WWW document]. URL http://www.statssa.gov.za/?page id=3955.

Statistics South Africa (2015) Monthly incomes. [WWW document]. URL http://www.statssa.gov.za/?s=monthly+income\&sitem=publications (accessed on February 2016).

Steyn, L. (2013) The black-belt economy kicks in. Mail \& Guardian. [WWW document]. URL http://mg.co.za/article/2013-05-03-00-the-black-belt-economy-kicks-in (accessed on 15 May 2014).

Solomon, M.R. (1999) The value of status and the status of value. In Consumer Value: A Framework for Analysis and Research (ed. by M.B. Holbrook), pp. 64-84. Routledge, London.

Soltani, I. \& Gharbi, J. (2013) The experiential value of online retailing: a scale development and validation from the consumer's perspective. Global Journal of Management and Business Research Marketing, 13, 2249-4588.

Sundie, J., Griskevicius, V., Vohs, K., Kendrick, D., Tybur, J. \& Beal, D. (2011) Peacocks, Porches and Thorstein Veblen: conspicuous consumption as a sexual signalling system. Journal of Personality and Social Psychology, 100, 664-680.

Tangri, R. \& Southall, R. (2008) The politics of Black Economic Empowerment in South Africa. Journal of South African Studies, 34, 699-716.

Terreblanche, M., Durrheim, K., \& Painter, D, (eds) (2006). Research in practice: applied methods for the social sciences. 2nd ed. UCT Press, Cape Town.

The Coca-Cola Retailing Council. (2010) Retailing in emergent markets: Strategic foundations and best practices. [WWW document].URL http://www.wpp.com/NR/rdonlyres/A6B7F2339670-420E509E3E32E82F47/0/CCRRC Retailing in Emergent Markets sep10.pdf (accessed on 12 April 2012).

Tavakol, M., \& Dennick, R. (2011). Making sense of Cronbach's alpha. International Journal of Medical Education, 2, 53.

Trigg, A. (2001) Veblen, Bourdieu, and conspicuous consumption. Journal of Economic Issues, 35, 99-115. 
Truong, Y., Simmons, G., McColl, R. \& Kitchen, P. (2008) Status and conspicuousness - are they related? Strategic marketing implications for luxury brands. Journal of Strategic Marketing, 16, 189-203.

Tustin, D.H., Ligthelm, A.A., Martins, J.H. \& Van Wyk, H.J. (2005) Marketing Research in Practice. University of South Africa, Pretoria.

Üstüner, T. \& Holt, D. (2009) Toward a theory of status consumption in less industrialized countries. Journal of Consumer Research, 37, 37-56.

Van der Berg, S. \& Louw, M. (2004) Changing patterns of South African income distribution towards time series estimates of distribution and poverty. South African Journal of Economics, 72, 546-572.

Van Kempen, L. (2007) Status consumption and ethnicity in Bolivia: Evidence from durables ownership. International Journal of Consumer Studies, 31, 76-89.

White, T. (2011) Global Investing. Emerging Market Spotlight Retail in South Africa: Making an Impression. Thomas White International, Ltd, Chicago.

Winkelmann, R. (2012) Conspicuous consumption and satisfaction. Journal of Economic Psychology, 33, 183-191. 